\title{
NATURE PROTECTION IN NATAL AND ZULULAND
}

(With acknowledgments to the Report of the Natal Parks, Game and Fish Preservation Board, April, 1951, to March, 1952.)

Extracts from the previous report, with a list of reserves and a map were given in Oryx, Volume I, No. 5, pages 235-242.

\section{Noumu Game Reserve}

Poaching.-A full-time resident ranger was appointed to this reserve in October, with instructions to ensure that every clause of the wild life protection ordinances was to be strictly enforced, to ensure the survival and increase of those animals that have survived years of snaring and hunting. The subsequent results have shown the necessity for his presence and afford ample proof of the good work he is doing.

Prosecutions and convictions have been too numerous for this report and have covered a variety of offences, many of them serious. Two Europeans were convicted of shooting in the reserve and although only fined $£ 1$, a jeep and two rifles were declared forfeit.

Water Supply.-Water levels in the various pans have dropped considerably as a result of prevailing drought conditions. The large Banzi Pan has dried up completely and it is hoped that it may, this coming year, be restored as a natural bird sanctuary and game watering place, by floods from the Usutu and Pongolo rivers. The Nyamiti Pan still contains a great volume of water but being of a brackish nature it is not so suitable as a drinking place for game. The position for game is inevitably aggravated by the drying-up of any pans, because animals face much danger along the northern border should they choose to drink at the Usutu River, where native kraals and cultivated fields extend all along the banks.

\section{ST. Lucia}

The first report of the complete closing of the St. Lucia mouth (through silting-up, $E d$.) was received on the 20th April, 1951. The existence of the firm "bar" at the estuary mouth caused an unusual rise in the lake level and led to the flooding of Fanies Island and to the formation of small pans. These latter have brought much aquatic bird life within sight of the camp, but on the true " bird islands" the avian inhabitants have been less numerous than in former years. 
Many interesting ornithological observations were made which space prevents being recorded here, but of considerable note was that the pelicans laid their eggs but appeared immediately to desert, leaving hundreds of deserted nests. The closing of the St. Lucia Lake will lead and has already led to an incalculable upsetting of the balance of nature and it is possible, albeit pure conjecture, that these pelicans realized that the fish population was already inadequate to maintain a large and voracious colony of young birds. If water levels continue to rise the bird islands may well be lost as a result of flooding, whilst it is almost certain that the breeding colonies will soon be endangered.

\section{Giant's Castle}

Fires.-As in previous years the burning of immensely long firebreaks for some weeks occupied much of the Game Conservator's mind and time. Unseasonable gales during June meant that the breaks had to be burnt under unusually difficult conditions. The early spring saw some strenuous work putting out fires that had entered or were approaching the reserve from outside, but the efforts were happily successful in all instances. As usual no help was obtained from neighbours either with fire fighting or firebreak burning and the Board continues to have to employ togt labour to assist with combating the fire hazard.

Poaching.--So far as is known no eland were killed actually in the reserve by illegal hunting, but at least three were destroyed on adjoining farms. In two of these cases culprits were arrested by game guards or by the South African Police. The Police Station Commander at Ntabamhlope is commended for his most praiseworthy efforts in bringing to trial and obtaining convictions of some of the natives involved in eland killing in the Ncibidwane valley. The most serious case of the year occurred when game guards arrested a party of five natives who had killed an eland. The prisoners having refused to be disarmed a fight developed. This resulted in the death of one of the Board's servants, who was stabbed with an assegai, as well as one of the poachers, who was thereafter shot in self defence. Three other natives were subsequently committed for trial on a charge of murder and received sentences of eight years each. It has to be reported with regret that it is considered the incident would not have happened had a more serious view been taken in the past against illegal hunting by gangs, or were some specific legislation in existence to cope with such organized activities as distinct from individual poaching.

Horse Stabbing.-An unusual type of crime was experienced 
for some time after the death of the game guard mentioned in the preceding paragraph, and approximately up to the time of the trial of the natives accused of murder. This took the form of horse stabbing involving the game guard's mounts. Four horses were stabbed in the period but fortunately three recovered. No arrests were made and it has to be reported with regret that none are now expected.

Eland and other Antelopes.-It is the Game Conservator's considered opinion that there has been a fair increase in the eland population and as no count has been taken for two years it is hoped that one may be undertaken at a future date, preferably from the air.

It is encouraging that fair numbers of eland have been seen in portions of the reserve previously shunned, especially in those localities where in former years trespassing activities kept game animals away. Spring calving was good and although investigations being carried out into the habits of eland are not yet conclusive, it seems virtually a rule that breeding animals gather into large troops. One such of 110 animals was seen to contain 35 calves, another of 90 had 25 calves, whilst several smaller groups seen elsewhere at the same time were accompanied by young. Studies on the diet of eland were continued and although many shrubs that make up their winter diet are now known, there remain many gaps to be filled in our knowledge of their summer food.

Some straying took place towards the Loteni-Hlatimba valleys and on one occasion rangers had a strenuous time driving a troop of 26 out of that area, the animals being led by a truculent old bull who was most averse to being thwarted. The usual party of "old gentlemen" eland again took up their winter quarters in the vicinity of the rest camp and the Game Conservator's garden. Their fancies among his vegetables and flowers were to say the least of it exasperating and their contempt for law and order was such that they not infrequently sunned themselves on his front lawn!

The hard winter led to a considerable loss of condition among some eland, particularly yearling animals ; many of these latter became extremely thin and it is evident that in adverse seasons the falling-off in the grass is not so serious as the lack of other plants upon which they browse. To be prepared to remedy this deficiency in the event of future bad seasons, some selected areas where the characteristic appearance of the reserve will be unaffected, have been put down to willows which will be kept at shrub size. 
The numbers of smaller antelopes are satisfactory but the severe conditions towards the end of winter showed that severe weather plays a part in retaining the balance of nature even under natural conditions. Unavoidable casualties among wild creatures forcibly indicate the necessity for careful veld control to ensure successful wild life conservation. Many species that, as it is, depend upon the reserves for their survival would be sorely endangered were fire precautions not a first priority, and were runaway fires permitted to devastate their habitat in mid-winter.

Birds.-Black storks breed regularly and it may with confidence be claimed that the Drakensberg reserves constitute an area wherein many fine birds, particularly raptores, can live without being subjected to the persecution so regrettably evident elsewhere. Among them the lammergeyer perhaps take pride of place but there are numerous other valuable species, and many items of interest concerning them that cannot be dealt with in this report. It may be mentioned, however, that although not resident at these high altitudes, the large Remeron pigeons are visiting the reserve in increasing numbers to breed.

\section{Royal National Park and Rugged Glen.}

Game.--There has undoubtedly been an improvement in the numbers of small game and of birds. Mountain reedbuck, duiker, bushbuck and Vaal rhebuck have all increased, as have guineafowl and the two species of francolin.

Tree Planting and Wattle Eradication.-In accordance with the policy of planting indigenous and not exotic trees, some 1,200 wild chestnut and 1,000 yellow-woods were reared in boxes and later transplanted in the indigenous forest patches, where they are making excellent progress. The year has seen a great deal of work connected with attempts to eradicate the noxious silver wattle, as well as considerable experimentation with the chemical 2.4.D. It is too early to determine the efficacy of the latter so far as complete destruction of trees is concerned, but it has certainly stopped much flowering and seeding.

\section{OrIBI Gorge}

Flora.-The preservation of the natural vegetation will always be a matter of major importance in this reserve, because of the few areas remaining in southern coastal Natal where indigenous cover has not been extensively abused. In the early stages of the Board's assumption of responsibility over the gorge, as many as twenty-nine trees of the Kafir iron-wood 
Millettia caffra were found cut down. Thorough investigation of this crime brought to light many unsavoury details and the unexpected magnitude of the nefarious trade in sticks, for sale to visitors to south coast resorts. Several convictions were obtained for cases of tree cutting and it would seem that those anxious to perpetrate this particular crime are now operating elsewhere. Some vandalism by visitors has regrettably to be reported and there are still far too many persons who persistently pluck and uproot wild flowers of all descriptions, in spite of the existence of a wild flower road reserve. The offence is common in many parts of the Province. That the native too is playing his part in decimating our flora is evinced by the quantities of protected flowers hawked from door to door in the early mornings in most of our larger towns. It is hoped that legislation may be tightened up in this regard within the near future.

Fauna.-Because the boundaries of the gorge reserve are for the most part found along the tops of the krantzes, and little grassland is included, the few remaining oribi live chiefly on two or three adjacent farms. There they do little more than maintain their numbers but the owners of these farms are most anxious to conserve this attractive species and, as poaching is stopped, so it is hoped that an increase may become apparent.

Bird life is in profusion with many rare species occurring in the thick cover and as more of the beauty spots and view points can be opened up for visitors, the gorge will inevitably become a paradise for the evergrowing company of bird watchers.

Baboons and vervet monkeys are common. The position in regard to these animals is being carefully watched to ensure that if natural enemies are now absent, their numbers do not cause undue damage to the avifauna, or otherwise upset the balance of nature.

\section{KAMBERG}

Eland Domestication.-It has been decided that long-term experiments will take place at this reserve in the domestication of the eland, which, of all the antelopes, stands out as the species most likely to fit into modern domestic economy. Quite the most important feature of the year's activities has been the commencement of the project. Even in this short time there have been many interesting results from Mr. Wright's experiments and although there is no place for wishful thinking in a scheme that will inevitably cover many years, it looks as though a very great deal of value and scientific interest is to be expected from his enthusiasm for and competence in the work. 
Notes on the Fauna

Elephant.-Natal's last herd of elephant continues to flourish in the out of the way area the animals have chosen as their refuge and fortunately the terrain is one wherein there is little reason why they should not remain undisturbed. A little damage to native crops is occasionally reported but extensive investigation of complaints has been carried out by a ranger of the Board and in almost all cases they proved to be either gross exaggerations, or thefts by a creature whose footprints bear no resemblance to those of Loxondontae! No elephant casualties have been reported and it is hoped that some refugees from farther north may have augmented the herd.

Black Rhinoceros.-On 29th August, 1951, there occurred in the Hluhluwe Game Reserve the death of the famous old bull black rhinoceros Matilda, who in recent years must surely have become the most photographed individual animal in the world and been directly responsible for visits to the reserve by innumerable tourists. It is perhaps apposite that a brief obituary notice should here be recorded: Matilda has been known to Capt. Potter since 1929 at which time, although already very old, the animal had both his horns. It was not until 1934 that the posterior horn was lost, presumably as the result of a fight, and thereafter Matilda was looked upon as an easily identified freak and often referred to as a one-horned species! Although this rhinoceros was so widely known as "Matilda" it is not generally realized that his name dated only from the visits of Australian troops during World War II. It is perhaps no exaggeration to say that over the years hundreds of persons have been put to flight by Matilda's shuffling charges; for although he has never been unduly bad tempered or caused any damage, he was apt at times to resent intrusions when his admirers and their motor cars became too numerous or persistent. Generally speaking however he treated visitors and staff alike with complete indifference, if they kept a reasonable distance from him. To estimate his undoubtedly great age would be pure surmise, but the winters of recent years have seen him lose much condition and agility, and it came as no surprise when he passed away after an unusually long spell of cold and wet weather.

Square-lipped (or White) Rhinoceros.-An unusual accident befell a square-lipped rhinoceros near the Umfolozi Game Reserve. This animal became stuck in a small river and, in spite of terrific struggles, of which the signs were plain to see, it remained there for approximately twelve hours almost completely submerged in the water. Fortunately the ending was 
a happy one because a native constable, to whom the thanks of all conservationists are due, on his own initiative and with the help of some local natives, levered the animal free with long poles. The rhino suffered no ill effects.

Hippopotamus.-Some damage to crops by hippopotami is unfortunately a not infrequent occurrence and this involves land cultivated by both European and native African. In all reported cases investigations have been carried out, whilst assistance towards keeping the animals out of fields has been given where possible. In many instances the hippos have been persuaded to change their feeding grounds after being fired at by game guards with a shot gun, using very light shot.

In a few other cases, where the nature of the ground permits such measures, a low cable type of fence has been erected with marked success. Although the Board continues itself to erect some of these fences, it is of course impossible to do so in all areas where hippos occur. On two occasions the destruction of lone bulls, most persistent in their disregard of shot guns, was contemplated, lest their actions should cause undue damage, but both were ultimately forced to return whence they had come; one of them was even persuaded to move his habitat a distance of seven miles.

There is no denying the fact that further worries lie ahead; they are inevitable because of increased settlement and cultivation, to a degree that means it is not the encroachment of the mammal on human preserves, so much as man's invasion of the animals' age-old habitat. It is regrettably becoming all too apparent that one cannot say a certain area, such, for instance, as an estuarine lake system, is more than adequate for the conservation of hippopotami and that the animals should not be permitted elsewhere, because many such areas are incomplete as an ecological niche for the species. Some lakes and pans are or are becoming essentially saline and hippos may be forced to seek fresh water not only to drink, but also for their calving and the rearing of their young.

In the Zululand area the year recorded the death of seven hippos, most of them the result of wounds sustained in fighting. As might be expected a large proportion of such casualties is made up of young bulls, or even bull calves, such as are frequently killed by the older bull when they attempt to join a "school". Doubtless this is a provision of nature to ensure a keeping down of the numbers of males and it is of interest to have noted that hippo cows would seem well aware of this danger threatening male offspring. Cows with heifer calves are seen in close proxi- 
mity to numbers of adult animals, but cows with tiny bull calves have been noticed keeping very much on their own and often far from any others.

Similar diminishment of their colt foals is commonly affected by zebra stallions and like practices among gregarious mammals are perhaps of more common occurrence than generally believed. The whole subject is one deserving of further study and in the same regard it was of interest to have read an account of a vicious attack against a colt foal by a New Forest pony stallion in England, describing the mare's vain endeavours to drive off her spouse.

These few notes on hippo incidents would be incomplete were they not to record the regrettable death on 20th March of the young hippo bull (also killed by an older male), affectionately known as "Peeping Tom". This animal who, because of his wanderings and adventures in the St. Lucia Township, was admired by many and cursed by a few, had become quite notorious and it is unfortunate that he, like the more famous "Matilda" should be no longer with us.

Giraffe.-The bull giraffe whose tameness is becoming notorious continues his role as a fairly regular contributor of news items and two of the latter would seem worthy of record; the first concerning his love of human attention, the second his overweening curiosity or airmindedness. On one occasion a nagana research official noticed that the animal was carrying many ticks. As this official had been hand-dressing and spraying the tsetse fly bait cattle, he had the necessary equipment in his jeep and decided to spray the bull giraffe. By standing on top of his vehicle it was possible to reach high enough to do this and, far from resenting the liberty, the giraffe appeared so to enjoy the treatment that it insisted upon following the jeep about for some while afterwards. The second incident took place when the giraffe was on the landing strip where plane refuelling takes place. As soon as a helicopter had landed the animal walked across to it, first viewed the rotors from above, next craned his neck down for a close inspection of the interior of the cockpit, and finally gave the tail rotor a good licking over before moving off into the bush.

Warthog.- For some time in the dry season a large warthog habitually grazed on the lawns around the Chief Conservator's house ; this uninvited guest refused to be driven off or intimidated by a setter dog and not infrequently chased the latter away.

Waterbuck.-In May a waterbuck bull died fighting and the 
carcase was later recovered from the Hluhluwe River with at least ten horn wounds in its body. Col. Stevenson Hamilton in his Wild Life records waterbuck among prey taken by crocodile, but a common native superstition exists that waterbuck are not molested by the saurians and local inhabitants were not surprised that the carcase in the river had not been touched. Many natives wear anklets made from waterbuck hide for wading in crocodileinfested waters ; their theory is that a waterbuck when pursued by dogs will make for water and, knowing this, the crocodile will ignore the buck and await the dogs, which it assumes will follow.

\section{General (Natal Reserves)}

Game Laros and Regulations.--During the year the close season for game was altered to from 16th September to 31st May, the delay of one fortnight before the commencement of the shooting season allowing many species to attain a little more maturity. Desirable though this has been there is no doubt whatsoever that the shooting season as a whole is too long for at least three good reasons. The first, that by September the veld has been so extensively burnt over wide areas and the amount of good cover remaining is so scanty, that the rate of slaughter and extent of disturbance is needlessly high. The second, that although guineafowl may still be in flocks, many francolins have been found to be very near breeding in September or in rarer instances already with eggs. The third, that although birds may not be materially affected it is certainly a fact that the pregnancy of many bushbuck and duiker is far too advanced in September for them to be hunted.

Protection of Birds.-Breaches of the Province's ordinance and the Union's act for the protection of birds continues to be so rife that it was no exaggeration of the position by an eminent biologist who recently visited southern Africa, studying its conservation, when he wrote : "Sentiment for bird protection is even less developed. ... The law which greatly restricts the caging of native birds is so generally disregarded that the enforcement problem ranks close behind the illegal drug and diamond traffic." The proposed tightening-up of the regulations if put into effect will clean up a state of affairs that is at the moment a disgrace to our country. 